\title{
Rapid stimulation of cyclic AMP production by aldosterone in rat inner medullary collecting ducts
}

\author{
E A Sheader, E T Wargent, N Ashton and R J Balment \\ School of Biological Sciences, University of Manchester, G.38 Stopford Building, Oxford Road, Manchester M13 9PT, UK \\ (Requests for offprints should be addressed to N Ashton; Email: nick.ashton@man.ac.uk) \\ (E T Wargent is now at Clore Laboratory, University of Buckingham, Hunter Street, Buckingham MK18 1EG, UK)
}

\begin{abstract}
Aldosterone stimulates sodium transport in the inner medullary collecting duct (IMCD) via the classic genomic pathway, but it is not known whether it also acts via a rapid, non-conventional pathway in this part of the nephron. The IMCD regulates the final sodium content of urine and expresses vasopressin receptors coupled to adenylate cyclase. The recently reported rapid, nongenomic actions of aldosterone have been associated mainly with an increase in intracellular $\mathrm{Ca}^{2+}$; however, it has also been shown to stimulate cAMP generation. Thus the aim of this study was to determine whether aldosterone stimulates rapid generation of cAMP in isolated IMCD segments. IMCD segments were microdissected from Sprague-Dawley rat kidneys and incubated at $37^{\circ} \mathrm{C}$ for $4 \mathrm{~min}$ with aldosterone $\left(10^{-12}\right.$ to $\left.10^{-6} \mathrm{M}\right)$, vasopressin $\left(10^{-12}\right.$ to $\left.10^{-6} \mathrm{M}\right)$, or a combination of hormones
\end{abstract}

in the presence of a phosphodiesterase inhibitor. cAMP was measured by radioimmunoassay. While corticosterone and dexamethasone were ineffective, aldosterone stimulated a dose-dependent increase in cAMP within $4 \mathrm{~min}$ $(P<0 \cdot 05)$. This action of aldosterone was not inhibited by the MR antagonist spironolactone. Co-incubation of aldosterone with vasopressin resulted in a further increase in cAMP generation above that induced by the neurohypophysial hormone alone. Aldosterone-mediated cAMP generation was not inhibited by a vasopressin $V_{1}$ or $V_{2}$ receptor antagonist. These data support a novel and rapid, non-genomic effect of aldosterone in IMCD. Aldosterone does not apparently interact with the vasopressin receptor to stimulate cAMP generation.

Journal of Endocrinology (2002) 175, 343-347

\section{Introduction}

In recent years aldosterone has been shown to exert rapid, non-genomic effects in a number of tissues, including the kidney (Harvey \& Higgins 2000), colon (Maguire et al. 1999) and vascular smooth muscle (Christ et al. 1995), as well as human mononuclear leukocytes (Wehling et al. 1987). These effects do not appear to be mediated via the classical type 1 mineralocorticoid receptor (MR), but rather by a distinct membrane-associated receptor whose identity has yet to be fully described. While the structure of this receptor remains obscure, there is a growing body of work describing the signal transduction pathways which link receptor activation to the rapid actions of aldosterone. To date, the pathway most commonly reported involves intracellular $\mathrm{Ca}^{2+}$; however, aldosterone has also been shown to stimulate rapid generation of cyclic AMP (cAMP) in porcine coronary vascular smooth muscle cells (Christ et al. 1999).

Aldosterone's classic target site is the principal cells of the cortical collecting duct; however, it has also been shown to stimulate sodium transport in the inner medullary collecting duct (IMCD) (Stokes 2000). The IMCD comprises three morphologically distinct regions: the outer segment, $\mathrm{IMCD}_{1}$, which consists of principal and intercalated cells similar to those in the outer medullary collecting duct, the middle segment, $\mathrm{IMCD}_{2}$, which is a mixture of principal, intercalated and IMCD cells, and the inner segment, $\mathrm{IMCD}_{3}$, which consists solely of IMCD cells (Tisher \& Madesen 1996). In vivo micropuncture studies have demonstrated that aldosterone is able to stimulate sodium reabsorption via the type $1 \mathrm{MR}$ in IMCD (Uhlich et al. 1969), but it is not known whether it also exerts a rapid, non-genomic effect in this part of the nephron.

The major aim of this study was to determine whether aldosterone can stimulate rapid generation of cAMP in IMCD segments. We have also investigated the potential interaction between aldosterone and vasopressin in view of the sensitivity of IMCD to vasopressin via its $\mathrm{V}_{2}$ receptor coupled to adenylate cyclase (Wargent et al. 1999).

\section{Materials and Methods}

Male Sprague-Dawley rats (200-250 g body weight; Charles Rivers Ltd, Margate, Kent, UK) were maintained 
on a $12 \mathrm{~h}$ light: $12 \mathrm{~h}$ darkness cycle and allowed free access to water and food (CRM; Labsure, Manea, Cambs, UK). Unless stated, all chemicals were obtained from Sigma Chemical Co (Poole, Dorset, UK).

\section{Microdissection and isolation of IMCD segments}

On the day of experimentation, rats were anaesthetized with $60 \mathrm{mg} / \mathrm{kg}$ Sagatal (pentobarbitone sodium; Rhone Merieux Ltd, Harlow, Essex, UK). The abdominal aorta was cannulated and, on occlusion of the aorta immediately above the left renal artery, the left kidney was perfused with $5 \mathrm{ml}$ ice-cold Hanks-HEPES medium (137 mM $\mathrm{NaCl}, \quad 5 \mathrm{mM} \quad \mathrm{KCl}, \quad 0.4 \mathrm{mM} \quad \mathrm{NaH}_{2} \mathrm{PO}_{4}, \quad 0.8 \mathrm{mM}$ $\mathrm{MgSO}_{4} \cdot 7 \mathrm{H}_{2} \mathrm{O}, 4 \mathrm{mM} \mathrm{NaHCO}_{3}, 0.44 \mathrm{mM} \mathrm{KH}_{2} \mathrm{PO}_{4}$, $1 \mathrm{mM} \mathrm{MgCl}, 2 \mathrm{mM} \mathrm{CaCl}$, $5 \mathrm{mM}$ D-glucose, $10 \mathrm{mM}$ $\mathrm{CH}_{3} \mathrm{COONa} \cdot 3 \mathrm{H}_{2} \mathrm{O}, 20 \mathrm{mM} \mathrm{N}-2$ hydroxyethylpiperazine-N-2-ethanesulphonic acid (HEPES), 6\% dextran $(\sim 87000 \mathrm{kDa})$ and $0 \cdot 1 \%$ bovine serum albumin (BSA; fraction $\mathrm{V}$, fatty acid free), $\mathrm{pH} \mathrm{7 \cdot 4)}$ followed by $4 \mathrm{ml}$ ice-cold $550 \mathrm{U} / \mathrm{ml}$ collagenase (Worthington Biochemical Corp., Lakewood, NJ, USA) in Hanks-HEPES. The left kidney was removed, decapsulated and a $1-2 \mathrm{~mm}$ thick slice taken through the cortico-medullary axis. 'Pyramids' of tissue (1-2 mm wide) were peeled from this slice and incubated for $20 \mathrm{~min}$ in an aerated $\left(95 \% \mathrm{O}_{2} / 5 \% \mathrm{CO}_{2}\right)$ solution of $110 \mathrm{U} / \mathrm{ml}$ collagenase in Hanks-HEPES. After repeated rinsing of the tissue in ice-cold Hanks-HEPES, IMCD segments $(0 \cdot 3-1 \mathrm{~mm}$ in length) were dissected out, on ice, under an inverted microscope and transferred singly in $2 \mu \mathrm{l}$ Hanks-HEPES onto cavity slides pretreated with Sigmacote (Sigma) followed by $0.5 \%$ BSA and dried between both applications. Another cavity slide was inverted over the first and the two sealed with petroleum jelly. Individual tubules were photographed using an image-capturing system (VGACAM; Electrim Corporation, Princeton, NJ, USA) to enable measurement of tubule length.

\section{Experimental protocol}

The slides were preincubated for $10 \mathrm{~min}$ at $35^{\circ} \mathrm{C}$. The incubation period was initiated by the addition of $2 \mu \mathrm{l}$ incubation medium containing the phosphodiesterase inhibitor 3-isobutyl-1-methylxanthine (IBMX), made up in dimethylsulphoxide (DMSO) and added to HanksHEPES so that the final concentration of IBMX was $1 \mathrm{mM}$ and the final concentration of DMSO was $0 \cdot 1 \%$ ( $\mathrm{v} / \mathrm{v})$, and $1 \mathrm{mg} / \mathrm{ml}$ bacitracin. To establish hormonestimulated cAMP production, the incubation medium also contained aldosterone, corticosterone, dexamethasone or arginine vasopressin (AVP) in a concentration range of $10^{-12}$ to $10^{-6} \mathrm{M}$. Co-incubations of aldosterone and AVP were performed at an AVP concentration range of $10^{-12}$ to $10^{-6} \mathrm{M}$ with either $10^{-10}$ or $10^{-6} \mathrm{M}$ aldo- sterone. Steroids were solubilised in ethanol, the final concentration in the incubation medium being $0.05 \%$ $(\mathrm{v} / \mathrm{v})$.

To investigate the potential involvement of the conventional MR in this rapid aldosterone-induced cAMP accumulation, tubules were preincubated with $1 \mu \mathrm{l}$ incubation medium containing $1 \mathrm{mM}$ spironolactone (MR antagonist) for $10 \mathrm{~min}$ at $35^{\circ} \mathrm{C}$ prior to incubation with $1 \mu \mathrm{l}$ aldosterone in incubation medium. In this experiment, spironolactone and aldosterone were solubilised in propan-1,2-diol, the final concentration at the incubation step being $0 \cdot 1 \%$. The slides were resealed and incubated for $4 \mathrm{~min}$ at $37^{\circ} \mathrm{C}$. In order to determine whether aldosterone was interacting with the vasopressin receptor, a further experiment was performed in which tubules were co-incubated with aldosterone $\left(10^{-6} \mathrm{M}\right)$ and either the AVP $\mathrm{V}_{1}$ antagonist $\left(\mathrm{d}\left(\mathrm{CH}_{2}\right)_{5}{ }^{1}, \mathrm{Tyr}(\mathrm{Me})^{2}, \mathrm{Arg}^{8}\right)_{-}$ vasopressin $\left(10^{-4} \mathrm{M}\right)$ (Kruszynski et al. 1980; Bachem (UK) Ltd, Saffron Walden, Essex, UK) or the AVP V 2 antagonist $\left(\mathrm{d}\left(\mathrm{CH}_{2}\right)_{5}{ }^{1}\right.$, D-Ile ${ }^{2}, \mathrm{Ile}^{4}, \mathrm{Arg}^{8}$, Ala- $\left.\mathrm{NH}_{2}{ }^{9}\right)$-vasopressin $\left(10^{-4} \mathrm{M}\right)$ (Sawyer et al. 1988; Bachem).

In all experiments, the 4-min incubations were terminated by aspirating the tubules in $1 \mu \mathrm{l}$ aspiration medium $(1 \mathrm{mg} / \mathrm{ml} \mathrm{BSA}$ and $1 \mathrm{mM}$ IBMX in deionised water) and $1 \mu \mathrm{l}$ incubation medium into Durham soda glass tubes (35 $\times 8 \mathrm{~mm})$ containing $20 \mu \mathrm{l}$ formic acid in ethanol $(5 \%$, $\mathrm{v} / \mathrm{v}$ ), which were then dried overnight at $40{ }^{\circ} \mathrm{C}$ and stored at $-20^{\circ} \mathrm{C}$ until radioimmunoassay for cAMP content.

\section{cAMP measurement}

cAMP levels were determined by radioimmunoassay using the protocol developed by Harper \& Brooker (1975) and incorporating acetylation of cAMP. Samples and standards were allowed to equilibrate to room temperature and then acetylated by addition of $1 \mu \mathrm{l}$ of a 2:1 mix of triethylamine: acetic anhydride and tubes allowed to stand for $10 \mathrm{~min}$ before being transferred to ice. After acetylation, $20 \mu \mathrm{l}$ $\left[{ }^{125} \mathrm{I}\right]$ cAMP (adenosine $3^{\prime}, 5^{\prime}$-cyclic phosphoric acid $2^{\prime}$-O-succinyl 3-[ $\left.{ }^{125} \mathrm{I}\right]$ iodotyrosine methyl ester; specific activity $2000 \mathrm{Ci} / \mathrm{mmol}, 3000$ c.p.m. $/ 20 \mu$; Amersham International plc, Amersham, Bucks, UK) in phosphate buffer $\left(39 \mathrm{mM} \mathrm{KH}{ }_{2} \mathrm{PO}_{4}, 48 \mathrm{mM} \mathrm{K}_{2} \mathrm{HPO}_{4}\right.$ and $7.7 \mathrm{mM}$ $\mathrm{NaN}_{3}, \mathrm{pH}$ 6.2) and $20 \mu \mathrm{l}$ anti-cAMP (Calbiochem, Beeston, Nottingham, UK) at a final dilution of 1:3000 in phosphate buffer, were added and all tubes vortexed and incubated for $24 \mathrm{~h}$ at $4{ }^{\circ} \mathrm{C}$.

The antigen-antibody complex was precipitated by the addition of $50 \mu \mathrm{l} 0.5 \%$ bovine $\gamma$-globulin (fractions II and III) and $250 \mu \mathrm{l} 16 \%$ polyethylene glycol (molecular weight 3350 ), each made up in phosphate buffer, $\mathrm{pH} 6 \cdot 8$. After $15 \mathrm{~min}$, the tubes were centrifuged at $2000 \mathrm{~g}$ and $5{ }^{\circ} \mathrm{C}$ for 20 min (Mistral 3000; MSE Scientific Instruments, Sanyo Gallenkamp plc, Loughborough, UK). The supernatant was then aspirated and the precipitate (bound fraction) counted for $10 \mathrm{~min}$ (Cobra II gamma counter; Canberra 


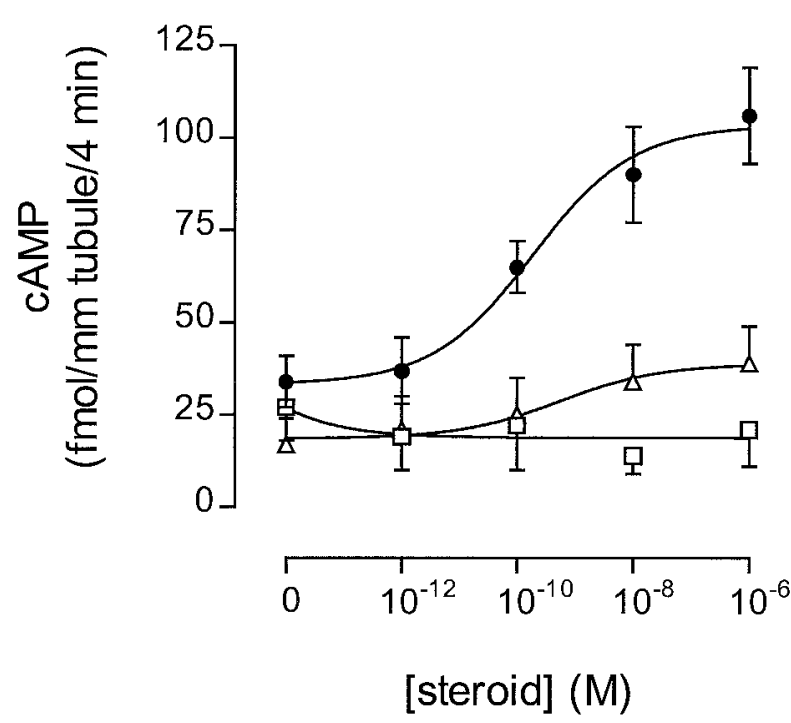

Figure 1 CAMP accumulation in IMCD segments incubated for 4 min with aldosterone $(\bullet)$, corticosterone $(\square)$ or dexamethasone $(\triangle)$. Each point represents the mean \pm S.E.M. of four to ten IMCD segments from three rats.

Packard, Pangbourne, Berkshire, UK). The lower limit of detection was $2.5 \mathrm{fmol}$ cAMP/tube. Inter- and intra-assay variabilities were $15 \cdot 7 \%$ and $12 \cdot 6 \%$ respectively.

\section{Data presentation and statistical analysis}

cAMP generation is expressed per 4-min incubation period per $\mathrm{mm}$ tubule. For each treatment, results are expressed as means \pm S.E.M. for the number of tubules $(n)$. Data were analysed by ANOVA followed by Scheffe's test; significance was ascribed at the 5\% level (SPSS for Windows, Ver. 10·1·0; SPSS UK Ltd, Woking, Surrey, UK).

\section{Results}

Basal cAMP accumulation during the 4-min incubation of IMCD was approximately $25 \mathrm{fmol} / \mathrm{mm}$ tubule. As indicated in Fig. 1 addition of corticosterone to the incubation in the range $10^{-12} \mathrm{M}$ to $10^{-6} \mathrm{M}$ had no effect on cAMP production. Addition of the glucocorticoid receptor agonist, dexamethasone, over the same concentration range was similarly without significant effect on the cAMP content of tubules. By contrast, the presence of aldosterone during the 4-min incubation produced a dose-dependent increase $(P<0 \cdot 05)$ in cAMP accumulation $\left(\mathrm{EC}_{50} 1 \cdot 2 \times 10^{-10} \mathrm{M}\right)$. The highest concentration of aldosterone $\left(10^{-6} \mathrm{M}\right)$ produced a fourfold increase to approximately $100 \mathrm{fmol}$ $\mathrm{cAMP} / \mathrm{mm}$ per $4 \mathrm{~min}$.

When the lowest concentration of aldosterone to produce a significant increase in cAMP $\left(10^{-10} \mathrm{M}\right)$ was

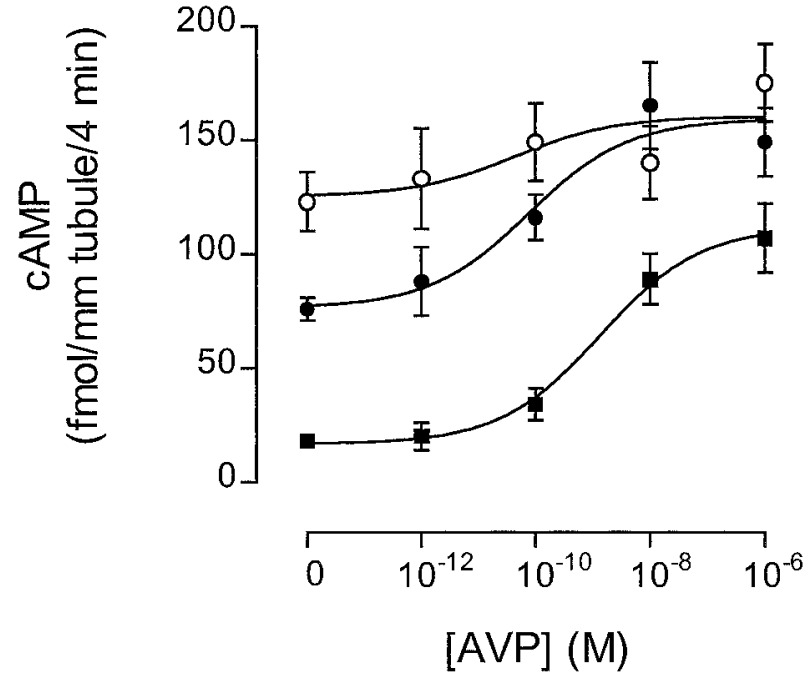

Figure 2 cAMP accumulation in IMCD segments incubated for 4 min with AVP alone $(\boldsymbol{\square})$, AVP and aldosterone $\left(10^{-10} \mathrm{M}\right)(\mathbf{0})$ or AVP and aldosterone $\left(10^{-6} \mathrm{M}\right)(\bigcirc)$. Each point represents the mean \pm S.E.M. of four to ten IMCD segments from three rats.

co-incubated with the type $1 \mathrm{MR}$ antagonist, spiranolactone $\left(10^{-3} \mathrm{M}\right)$, there was no affect on the resulting aldosterone-stimulated accumulation of cAMP ( $65 \pm 7$ vs $76 \pm 7 \mathrm{fmol} \mathrm{cAMP} / \mathrm{mm}$ tubule per $4 \mathrm{~min}$ ).

Incubation of IMCD segments with AVP (Fig. 2) produced a dose-dependent stimulation $(P<0 \cdot 05)$ of cAMP similar to that observed with aldosterone, with maximal stimulated levels of $100 \mathrm{fmol} / \mathrm{mm}$ per $4 \mathrm{~min}$. As shown in Fig. 2 the addition of $10^{-10} \mathrm{M}$ and $10^{-6} \mathrm{M}$ aldosterone alone (no AVP) again produced an increase in cAMP accumulation comparable with measures shown in Fig. 1. Co-incubation of tubules with aldosterone $\left(10^{-10} \mathrm{M}\right.$ or $\left.10^{-6} \mathrm{M}\right)$ with increasing concentrations of AVP resulted in further increases in cAMP accumulation $\left(\mathrm{EC}_{50} 1.4 \times 10^{-10} \mathrm{M}\right.$ and $1.4 \times 10^{-6} \mathrm{M}$ respectively). This was additive in nature, at least at the lower doses of vasopressin, with an apparent maximum stimulated cAMP level of approximately $150 \mathrm{fmol} / \mathrm{mm}$ per $4 \mathrm{~min}$ with the highest combined doses. This apparent higher upper limit of stimulated cAMP was independent of the concentration of aldosterone employed.

Aldosterone $\left(10^{-6} \mathrm{M}\right)$-stimulated cAMP production $(138 \pm 9, n=23)$ in IMCD was not inhibited by coincubation with either $10^{-4} \mathrm{M} A V P V_{1}$ receptor antagonist $(181 \pm 20, n=19)$ or $10^{-4} \mathrm{M}$ AVP $\mathrm{V}_{2}$ receptor antagonist $(169 \pm 19 \mathrm{fmol} \mathrm{cAMP} / \mathrm{mm}$ tubule per $4 \mathrm{~min}$, $n=21)$.

\section{Discussion}

This study has clearly shown for the first time that aldosterone is able to induce a rapid increase in cAMP in 
IMCD segments in vitro. This effect appears specific to aldosterone, as neither corticosterone nor the glucocorticoid receptor agonist, dexamethasone, affected cAMP generation. Potential effects of corticosterone could have been inhibited by any $11 \beta$-hydroxysteroid dehydrogenase type $2(11 \beta-H S D 2)$ activity in the tubule preparation. However, the absence of an effect of dexamethasone, which is resistant to metabolism by $11 \beta-H S D 2$ (Stewart et al. 1995), implies that activation of the conventional $\mathrm{MR}$ is not responsible for the increase in cAMP induced by aldosterone. This contention is further supported by the lack of effect of $10^{-3} \mathrm{M}$ spiranolactone, the specific type $1 \mathrm{MR}$ antagonist, on the aldosterone-induced increase in cAMP. The rapid action of aldosterone (within $4 \mathrm{~min}$ ) is also consistent with a non-genomic mechanism. Furthermore, the half maximal effect was within the physiological range of free aldosterone in the rat $(0 \cdot 2 \mathrm{nM} / \mathrm{l})$ (Menachery et al. 1991, Musabayane et al. 1994) and was comparable with that previously reported for rapid actions of aldosterone in other tissues $(0 \cdot 1-0 \cdot 2 \mathrm{nM} / \mathrm{l})$ (Wehling et al. 1987, Christ et al. 1995). These characteristics are typical of the reported non-genomic actions of aldosterone in other tissues, strongly suggesting that the IMCD is also a target site for a novel, rapid action of aldosterone.

The molecular identity of the receptor which mediates aldosterone's rapid effects is unknown; however, binding studies have identified high-affinity binding sites for aldosterone in membranes from various cells, which probably represent a membrane-bound receptor. It is unlikely that this receptor is a modified form of the classical MR, which shows similar affinity for aldosterone and cortisol/ corticosterone, as attempts to characterise the receptor in porcine coronary artery smooth muscle indicate high selectivity for aldosterone over other steroids (Christ et al. 1999). It is also noteworthy that skin cells from MR knockout mice continue to exhibit a rapid increase in both cAMP and $\mathrm{Ca}^{2+}$ in response to aldosterone (Haseroth et al. 1999).

In the present study, we have investigated the possibility that aldosterone may interact with vasopressin receptors localised in the IMCD and/or activate a common pool of adenylate cyclase. Neither the AVP $V_{1}$ nor the $V_{2}$ receptor antagonists employed was able to block the effect of aldosterone, suggesting that aldosterone does not interact with either subtype of AVP receptor in the IMCD. The maximum cAMP levels achieved when AVP or aldosterone were administered separately were similar (approximately $100 \mathrm{fmol} / \mathrm{mm}$ tubule per $4 \mathrm{~min}$ ). However, when the two hormones were incubated in combination, although there was an increased response, the maximum levels of cAMP achieved (approximately $150 \mathrm{fmol} / \mathrm{mm}$ tubule per $4 \mathrm{~min}$ ) were less than the simple addition of the two separate responses. This would be consistent with both hormones acting upon common target cells, in which a common pool of ATP provided a limit to maximal cAMP generation. However, the potential heterogeneity of cell types present in the mixed population of IMCD segments used in these studies does not preclude the two hormones acting on separate cell types.

The physiological consequences of aldosterone-induced cAMP generation in IMCD cells remains to be established, though one possible target protein is the $\mathrm{Na}^{+} / \mathrm{H}^{+}$ exchanger (NHE) in this segment (Sun et al. 1998). Activity of NHE1 is stimulated by vasopressin acting through cAMP in the medullary thick ascending limb (Sun et al. 1990) and NHE1 has also been shown to be activated by cAMP in osteoblasts (Azarani et al. 1995). Aldosterone is known to stimulate $\mathrm{Na}^{+} / \mathrm{H}^{+}$exchange via a rapid, non-genomic mechanism in human mononuclear leukocytes (Wehling et al. 1987), rat vascular smooth muscle cells (Christ et al. 1995), amphibian distal nephron (Oberleithner et al. 1987) and renal Madin-Darby canine kidney (MDCK) cells (Gekle et al. 1996). This raises the possibility that aldosterone may also stimulate cAMP leading to activation of NHE in the IMCD. Nonetheless, increased cAMP in the IMCD has also been shown to influence anion and water transport and urea permeability.

In summary, we have shown for the first time that aldosterone induces a rapid, dose-dependent increase in cAMP in IMDC segments in vitro. This was not blocked by the type $1 \mathrm{MR}$ antagonist spironolactone and could not be mimicked by corticosterone or dexamethasone over the same concentration range, strongly suggesting that aldosterone was acting via a specific non-genomic mechanism. There appeared to be no interaction with the vasopressin receptor but the aldosterone response may involve a common adenylate cyclase and/or ATP pool.

\section{Acknowledgement}

E T W was funded by a National Kidney Research Fund studentship.

\section{References}

Azarani A, Orlowski J \& Goltzman D 1995 Parathyroid hormone and parathyroid hormone-related peptide activate the $\mathrm{Na}^{+} / \mathrm{H}^{+}$ exchanger NHE-1 isoform in osteoblastic cells (UMR-106) via a cAMP-dependent pathway. Journal of Biological Chemistry 270 23166-23172.

Christ M, Douwes K, Eisen C, Bechtner G, Theisen K \& Wehling M 1995 Rapid nongenomic effects of aldosterone on sodium transport in rat vascular smooth muscle cells: involvement of the $\mathrm{Na}^{+} / \mathrm{H}^{+}$ antiport. Hypertension 25 117-123.

Christ M, Günther A, Heck M, Schmidt BMW, Falkenstein E \& Wehling M 1999 Aldosterone, not estradiol, is the physiological antagonist for rapid increases in cAMP in vascular smooth muscle cells. Circulation 99 1485-1491.

Gekle M, Golenhofen N, Oberleithner H \& Silbernagl S 1996 Rapid activation of $\mathrm{Na}^{+} / \mathrm{H}^{+}$exchange by aldosterone in renal epithelial cells requires $\mathrm{Ca}^{2+}$ and stimulation of a plasma membrane proton conductance. PNAS 93 10500-10504. 
Harper JF \& Brooker G 1975 Femtomole sensitive radioimmunoassay for cyclic AMP and cyclic GMP after 2'O acetylation by acetic anhydride in aqueous solution. Journal of Cyclic Nucleotide Research $\mathbf{1}$ 207-218.

Harvey BJ \& Higgins M 2000 Nongenomic effects of aldosterone on $\mathrm{Ca}^{2+}$ in M-1 cortical collecting duct cells. Kidney International $\mathbf{5 7}$ 1395-1403.

Haseroth K, Gerdes D, Berger S, Feuring M, Günther A, Herbst C, Christ M \& Wehling M 1999 Rapid nongenomic effects of aldosterone in mineralocorticoid-receptor-knockout mice. Biochemical and Biophysical Research Communications 266 257-261.

Kruszynski M, Lammek B, Manning M, Seto J, Haldar J \& Sawyer WH 1980 [1- $\beta$-Mercapto- $\beta, \beta$-cyclopentamethylenepropionic acid),2-(O-methyl)tyrosine] arginine-vasopressin and [1- $\beta$-mercapto- $\beta, \beta$-cyclopentamethylenepropionic acid)] arginine-vasopressin, two highly potent antagonists of the vasopressor response to arginine-vasopressin. Journal of Medicinal Chemistry 23 364-368.

Maguire D, MacNamara B, Cuffe JE, Winter D, Doolan CM, Urbach V, O'Sullivan GC \& Harvey B 1999 Rapid responses to aldosterone in human distal colon. Steroids 64 51-63.

Menachery A, Braley LM, Kifor I, Gleason R \& Williams GH 1991 Dissociation in plasma renin and adrenal ANG II and aldosterone responses to sodium restriction in rats. American Journal of Physiology 261 E487-E494.

Musabayane CT, Ndhlovu CE, Forsling ML \& Balment RJ 1994 Interaction of aldosterone and oxytocin to influence renal sodium excretion in rats. Experimental Physiology 79 763-774.

Oberleithner H, Weigt M, Westphale H-J \& Wang W 1987 Aldosterone activates $\mathrm{Na}^{+} / \mathrm{H}^{+}$exchange and raises cytoplasmic $\mathrm{pH}$ in target cells of the amphibian kidney. PNAS $\mathbf{8 4}$ 1464-1468.
Sawyer WH, Bankowski K, Misicka A, Nawrocka E, Kruszynski M, Stoev S, Klis WA, Przybylski JP \& Manning M 1988 Potent $V_{2}$ vasopressin antagonists with structural changes at their C-terminals. Peptides 9 157-163.

Stewart PM, Whorwood CB \& Mason JI 1995 Type 2

$11 \beta$-hydroxysteroid dehydrogenase in foetal and adult life. Journal of Steroid Biochemistry and Molecular Biology 55 465-471.

Stokes JB 2000 Physiologic resistance to the action of aldosterone. Kidney International 57 1319-1323.

Sun AM, Saltzberg SN, Kikeri D \& Hebert SC 1990 Mechanisms of cell volume regulation by mouse medullary thick ascending limb of Henle. Kidney International 38 1019-1029.

Sun AM, Liu Y, Centracchio J \& Dworkin LD 1998 Expression of $\mathrm{Na}^{+} / \mathrm{H}^{+}$exchanger isoforms in inner segment of inner medullary collecting duct (IMCD $)_{3}$ ). Journal of Membrane Biology 164 293-300.

Tisher CC \& Madesen KM 1996 Anatomy of the kidney. In The Kidney, pp 3-71. Ed. BM Brenner. Philadelphia: WB Saunders.

Uhlich E, Baldamus CA \& Ullrich KJ 1969 The effect of aldosterone on sodium transport in the collecting ducts of the mammalian kidney. Pflïgers Archiv 308 111-126.

Wargent ET, Burgess WJ, Laycock JF \& Balment RJ 1999 Separate receptors mediate oxytocin and vasopressin stimulation of cAMP in rat inner medullary collecting duct cells. Experimental Physiology 84 $17-25$.

Wehling M, Armanini D, Strasser T \& Weber PC 1987 Effect of aldosterone on the sodium and potassium concentrations in human mononuclear leukocytes. American Journal of Physiology 252 E505-E508.

Received 10 July 2002

Accepted 23 July 2002 